\title{
路地空間におけるルールから逸脱する建築的実践
}

\author{
ースラム改善事業地のバンコク・70 ライ地区を事例としてー
}

\section{ILLEGAL CONSTRUCTION PRACTICES ON ALLEY SPACE}

The case study of 70 rai community, Klongtoey, the slum improvement project area, Bangkok, Thailand

\author{
阿部 拓 也*1, 清 水郁 郎*2
}

\section{Takuya ABE and Ikuro SHIMIZU}

\begin{abstract}
In this paper, illegal construction practices will be studied the living space in 70 rai community, Klongtoey, slum improvement project area, Bangkok, Thailand. We take up alley space which is formed by illegal construction practices. The aim of this paper will show the reason why people take the illegal way of construction to make their living in Klongtoey. The results are as follows;

1. There are the illegal construction practices on alley space.

2. Residents are doing illegal practices within acceptable level among them.

3. Residents see whether or not are prevailing among people, "anyone" had already done illegal practices.
\end{abstract}

Keywords : Illegal Construction Practices, Alley Space, Slum Improvement Project Area, Building Formats ルールから逸脱する建築的実践, 路地空間, スラム改善事業地, 建物形式

1. はじめに

\section{1-1. 研究背景 ·目的}

スラム注 1)を対象とした建築学の研究は、さまざまな観点から実 施されてきた。しかし、スラム改善事業地一クリアランス型開発注2) やサイト・アンド・サービス事業（以下、S\&S）注 3) などの事業地 一を対象に、計画者が導入した空間において諸制度から逸脱する建 築的実践に焦点を当てた研究はない。このような問題意識にもとづ き、本稿では、S\&S が実施されたバンコク・70 ライ地区を事例に、 ルールから逸脱する建築的実践について論じる。

スラムは、発展途上国の近代化とともに急増した注 ${ }^{4)}$ この問題に 対し、計画者はさまざまなスラム改善事業を立案することで対処し てきた注 5)。すなわち、計画者が介入し、区画整備や建物建設に関す る制度を整備することで、スラムの居住環境改善を試みてきた注 6)。

しかし、70 ライ地区の住民は、それらの枠組みから逸脱する建築 的実践を意図的におこなう。またその実践は、住民ごとに独立して いるわけではなく、住民間で共有された手法として定着しているよ うに映る。もしそうだとすれば、住民間で共有された枠組みからの 逸脱とは、住民の立場から別の枠組みを再構築することに他ならな い。このように、ルールから逸脱する建築的実践について明らかに することは、スラム改善事業の実効性を問うだけではなく、行政的 介入がありながら、なぜスラムは存続するのかという問題を突きつ ける。それは、都市スラムの新しい捉え方を提示することになる。 以上のような観点から、本稿では、ルールから逸脱する建築的実
践の実態およびそれらの実践がなぜおこなわれるのかを明らかにす ること、加えてそれをふまえたスラム改善事業に対する知見を得る ことを目的とする。第一稿となる本稿では路地空間に焦点を当て、 個々の住宅については別稿で論じる。

本稿で扱う資料は、2016 年 9 月 10 日〜24 日、2017 年 9 月 7 日 $\sim 30$ 日、 2018 年 4 月 2 日〜 10 月 4 日までの現地調査で収集した。 調査内容は、住宅の実測調查 ( 17 軒)、居住者への質問調查 $(21$ 人)、 路地平面図および立面図の実測調查（ソイ 12 ・ソイ 13 は 49 軒、 ソイ 28 は 30 軒)、70 ライ地区全体地図の作成（敷地面積、建物の

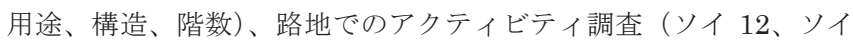
13、ソイ 28）である。以下では、スラムを対象とする先行研究につ いて検討したうえで、本稿の独自性を提示する。

\section{1-2. 先行研究の検討}

近年、スラムを対象とした研究では、計画者の想定とは異なる住 民のインフォーマルな実践に着目している。1970 年代以降、クリア ランス型開発に代わる計画の立案が急務となり、スラムの実態調査 を目的とした研究が始まった注 7)。そしてこれらの成果をもとに、 S\&S などの住民参加型事業が立案され、実施されていった。そして そのような事業の変化とともに、住民のインフォーマルな実践に着 目寸る研究が主流となり、その流れは現在まで続いている。

このような、スラムの住民のインフォーマルな実践に着目する研 究は、以下の 3 つに整理できる。1つ目は、不法占拠地区注8)を対象 に、スラムから独自の居住文化を見出そうと試みる研究である $\left.{ }^{6)}, 7\right) 。$
*1 フリーランス 修士(工学)

*2 芝浦工業大学建築学部建築学科 教授 · 博士 (文学)
Freelance, M.Eng.

Prof., School of Architecture, Shibaura Institute of Technology, Ph.D. 
2 つ目は、スラム改善事業地を対象に、計画意図とは異なる居住者 の実践に着目することで、スラム改善事業を批判的に検討する研究 である ${ }^{3), 8}$ 。3 3 目は、不法占拠地区と再開発地区が混在する地域を 対象に、フォーマルな開発の限界を指摘しながらも、それを補うも のとして、住民のインフォーマルな実践を位置づける研究である 9),10)。これらの研究における視点は、本稿にも継承されている。

上記の研究に対して本稿では、ルールから逸脱する建築的実践に 着目寸ることに独自性がある。本稿と同様の視点をもつ研究では、 地区の形成過程 6),7)や外部空間への生活財のあふれ出し 6),7),9)、伝統 的な慣習法や価值観の現存 7),9)、非正規な開発形態およびそのマネ ジメント 10)、「インフォーマル建築ルール」注9)に着目している。他 方、スラム改善事業地の研究に絞ると、計画意図とは異なる居住空 間の変容 ${ }^{3}$ 、インフォーマルな住宅供給 ${ }^{8}$ に着目している。しかし、 スラム改善事業地を対象に、居住者の実践を規制する制度およびそ れらから逸脱する実践に焦点を当てた研究はない。

それだけではなく本稿では、人類学における「ソフトレジスタン ス」論を参照する点にも独自性がある。「ソフトレジスタンス」論と は、「[構造的弱者が : 引用者注］押し付けられた法や規範を利用し て、その目論見とは別な多様なものを創造していく」実践を指す ${ }^{11)}$ この概念をもとに、ルールから逸脱する建築的実践を、住民が計画 者から一方的に与えられた空間や制度を解釈し、住民にとって都合 のいいように再構築する実践として捉える。この概念は居住空間に 適応できるか否かは現在まで検討されておらず、人類学においても 本稿が一定の貢献を果たすと考えられる。

ここまで、先行研究について整理してきた。以下では、70 ライ地 区成立の背景および再開発により導入された枠組みについて述べる。

\section{2. 調査対象地の概要}

\section{2-1. 70 ライ地区成立とその背景}

クロントイスラムはタイ最大のスラムである。チャオプラヤー河 沿岸にあるクロントイ港では、1937 年に港湾開発がおこなわれ、職 を求めた人々が地方から流入した。そして流入した人々が港湾局所 有の空き地を不法占拠した結果、スラムが形成された。

流入する人々に対して、港湾局による立ち退きが 1957 年ごろか ら実施され、1960 年以降多発した注10)。このような状況に対し、1960 年代後半から、住民は組織を形成することで立ち退きに抵抗した注 11)。結果として、住民は港湾局に対し、土地分有事業注 12) の実施お よび 20 年間の借地権を獲得した。

\section{2-2. クロントイ再開発計画と建設ルール}

クロントイ再開発計画は 1985 年に実施され、70 ライ地区では、 S\&S および区画整備がおこなわれた注 ${ }^{13}$ ）（Fig.1）。そこには、4 種

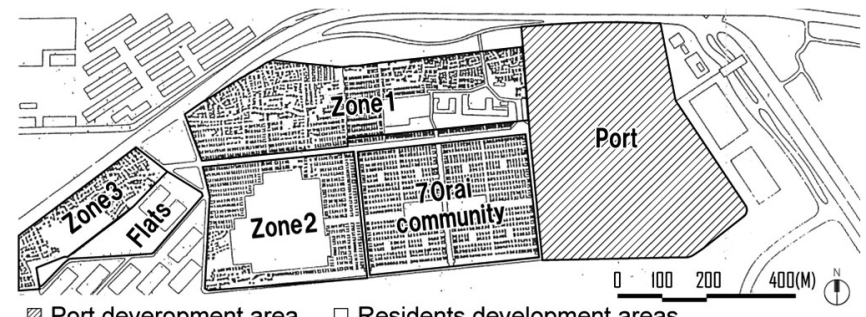

Port deveropment area $\square$ Residents development areas Fig. 1 Site of Klongtoey slum after redevelopment Source: Boonyabancha. et al.,1987
類の路地 $(12 \mathrm{~m} 、 9 \mathrm{~m} 、 6 \mathrm{~m} 、 2 \mathrm{~m}) 、 2$ 本の水路、防炎のための 3 種類 の空き地 $\left(3900 \mathrm{~m}^{2} 、 504 \mathrm{~m}^{2} 、 240 \mathrm{~m}^{2}\right)$ が計画された。その他、地区 南東には最貧困層が居住するバン・ガルンと呼ばれる地区がある。

計画段階では、62.5rai 注 ${ }^{14)}$ の土地を 1300 軒分の敷地に分割して いた注 ${ }^{15}$ )。敷地面積は 4 種類あり、居住人数に応じて供給された。 敷地は奥行き $10 \mathrm{~m}$ であり、間口のみ変化し、30 m² $60 \mathrm{~m}^{2} 、 90 \mathrm{~m}^{2} 、$ $120 \mathrm{~m}^{2}$ があった。70 ライ地区全体の土地は港湾局が所有し、建物は 居住者が所有していた。しかし 20 年間の借地権契約は終了し、現 在では 3 年毎に借地権を更新している注 16 )。

住民一の敷地もしくは建物の供給方式は、バン・ガルンと 70 ラ イ地区全体で異なる（Fig.2）。70 ライ地区全体では敷地のみ供給さ れ、建物は居住者が自力建設する計画だった注 17 )。建物建設には、 港湾局への申請が必要であり、建設ルールを遵守しなければならな かった。建設ルールとして、(1)敷地前面から $2 \mathrm{~m}$ のセットバック (2) 敷地両端および後方に $0.5 \mathrm{~m}$ のバッファーゾーンを設けること (3) 3 階建て以上の建設禁止がある。

一方バン・ガルンでは、敷地に加え、軍が建物を無償で供給した 12)。敷地は間口 $6 \mathrm{~m}$ 、奥行き $10 \mathrm{~m}$ が大半を占めていた。例外として、 バン・ガルンのソイ 28 南側では、敷地は間口 $6 \mathrm{~m}$ 、奥行き $17 \mathrm{~m}$ だ った。しかし住民は敷地後方 $7 \mathrm{~m}$ 部分の所有権を持っておらず、増 築は禁止されていた。供給された建物は、間口 $6 \mathrm{~m}$ 、奥行き $4 \mathrm{~m}$ の 1 室空間、1 階建ての長屋形式であり、路地際から $2 \mathrm{~m}$ セットバック した位置に建設された。バン・ガルンの建設ルールとして、(1)路地 際から $2 \mathrm{~m}$ のセットバック (2)増築可能な範囲は建物から後方 $4 \mathrm{~m}$ の み(3) 2 階建て以上の建設禁止がある。

以上をふまえて、本稿では建設ルールを遵守した建物を「建設ル ール型」と定義する注 18)。70 ライ地区に導入された枠組みについて 把握したところで、以下では、地区全体のスケールから現状の居住 空間について述べる。

\section{3. 居住空間の現状一地区全体一 \\ 3-1. 建物の用途}

70 ライ地区の空間構成は、1985 年から大きく変化していない。 路地幅員や空き地、水路は計画当初のままである。空き地には、住 民の生活財が多数置かれ、水路上には小屋が建設されている。住民

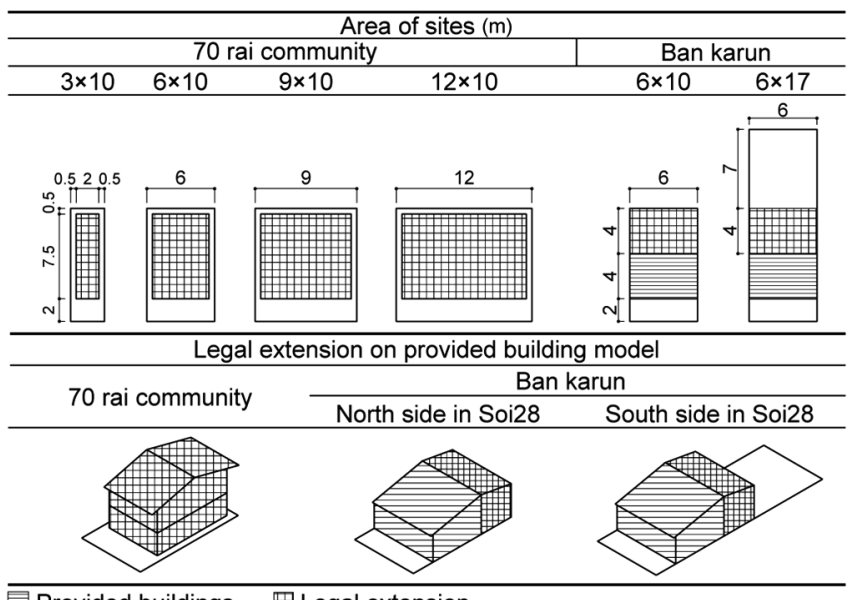

每Provided buildings 田 Legal extension

Fig.2 Area of sites and "Legal extension on provided building model" 


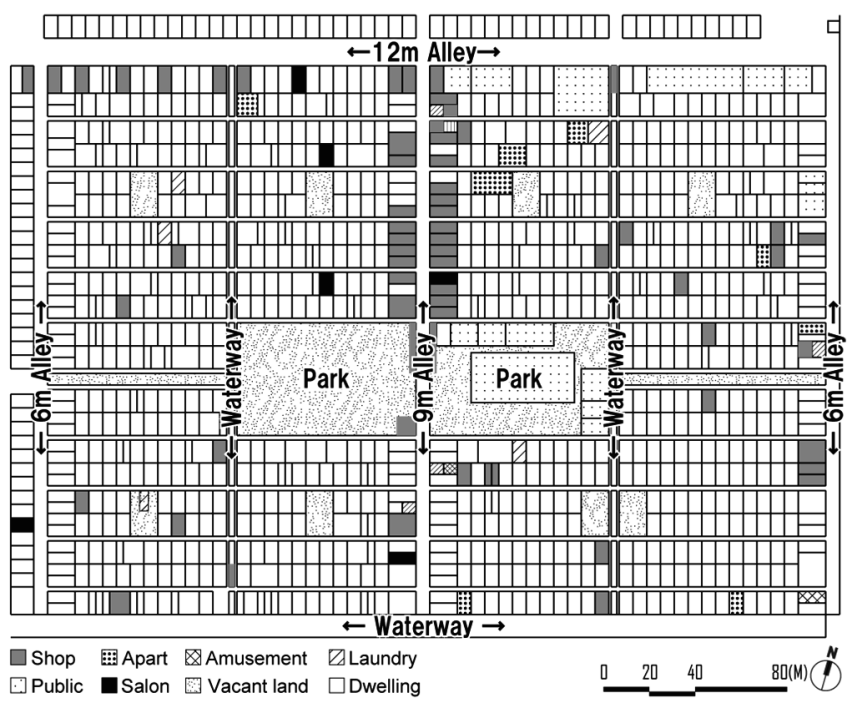

Fig. 3 The use of the buildings

は、それらの場所を生業や炊事、食事、洗濯、物置、交流、休息、 信仰などに活用している。

現状の建物数は 1011 軒であり、 $2 \mathrm{~m}$ 路地に居住専用の建物が集中 している（Fig.3）。一方、雑貨屋や飲食店、屋台、公共施設なども あり、これらは $12 \mathrm{~m}$ 路地と $9 \mathrm{~m}$ 路地に集中している。本稿では、住 民の日常生活の舞台となる $2 \mathrm{~m}$ 路地に焦点を絞り分析する (Fig.4)。 $2 \mathrm{~m}$ 路地に面寸る建物数は、70 ライ地区全体では 884 軒、うちバ ン・ガルンでは 198 軒である注19)。

\section{3-2. 敷地面積・建物の階数・建物の構造}

70 ライ地区における建物の特徴について、敷地面積、建物の階数、 建物の構造に着目して分析する。敷地面積は 5 つ $\left(30 \mathrm{~m}^{2} 、 60 \mathrm{~m}^{2} 、\right.$ $90 \mathrm{~m}^{2} 、 102 \mathrm{~m}^{2} 、 120 \mathrm{~m}^{2}$ 以上) 、建物の階数は $3 つ(1$ 階建て、2 階建 て、3 階建て以上)、建物の構造は 4 つ（コンクリート［以下、RC] 造、木造、 1 階 $\mathrm{RC}$ 造・ 2 階木造、その他）に分類できる。

これらを敷地面積・建物の階数・建物の構造ごとに 5 つに分類す る (Fig.4)。1つ目は、敷地面積 $60 \mathrm{~m}^{2} 、 2$ 階建て、1 階 RC 造・2階 木造である。2つ目は、敷地面積 $30 \mathrm{~m}^{2} \cdot 90 \mathrm{~m}^{2} \cdot 120 \mathrm{~m}^{2}$ 以上、2 階建 て、 1 階 $\mathrm{RC}$ 造・ 2 階木造である。 3 つ目は、敷地面積 $60 \mathrm{~m}^{2} 、 1$ 階 建て、RC 造である。4つ目は、敷地面積 $102 \mathrm{~m}^{2} 、 1$ 階建て、RC 造 である。5つ目は、敷地面積 $60 \mathrm{~m}^{2} \cdot 102 \mathrm{~m}^{2} 、 2$ 階建て、1 階 RC 造・ 2 階木造である。なお 5 つ目は、バン・ガルン特有の 2 階建てを指 している。詳しくは後述するが、2 階が路地から見えない位置にあ る建物を指す。上記以外はその他に分類する注 20)

これらを分析すると、70 ライ地区全体とバン・ガルンでは、建物 の特徴が異なることがわかる。70 ライ地区全体では、敷地は 4 つ (60 $\mathrm{m}^{2}$ が大半)、2 階建て、1 階 $\mathrm{RC}$ 造・2 階木造が多い。一方バン. ガルンでは、敷地は $2 つ\left(60 \mathrm{~m}^{2} \cdot 102 \mathrm{~m}^{2}\right) 、 1$ 階建て、 RC 造が多い。 以上を参考に、 70 ライ地区全体からソイ 12 とソイ 13 、バン・ガル ンからソイ 28 を選出し、路地空間について述べる（Fig.5）。

\section{4. 居住空間の現状一路地一}

\section{4-1. 路地空間の物理的特徵}

ここでは、路地空間の物理的特徴について、ソイ 13 をもとに述 ベる。ソイ 12 ・ソイ 13 とソイ 28 では、建物高さが異なる。前者は

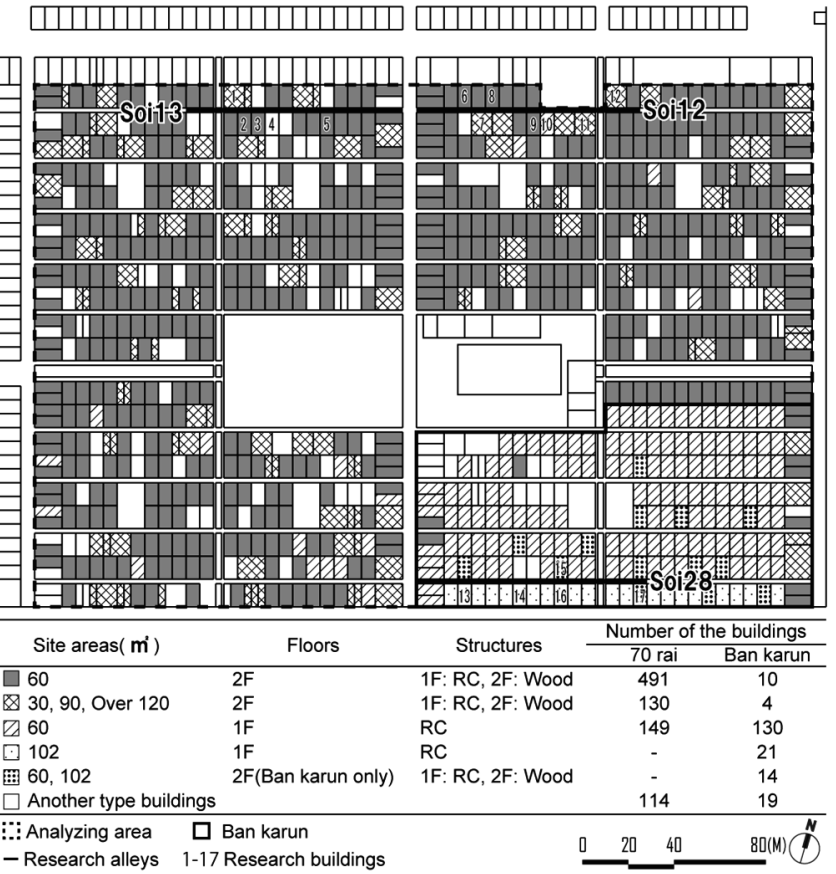

Fig.4 Analyzing area and number of the buildings

2 階建て、軒高は平均 $5 \mathrm{~m}$ である。一方、後者は 1 階建て、軒高は 平均 $2 \mathrm{~m}$ である。しかしそれ以外の要素で大きな違いはなく、以下 で述べる特徵は、ソイ 13 でより顕著な形で表れている。以上をふ まえて、本稿では、ソイ 13 に絞って分析をおこなう（Table1）。

路地における特徵の 1 つとして、路地幅員の狭さがある。建設ル ールに従うと、各建物は敷地前面から $2 \mathrm{~m}$ セットバックさせなけれ ばならない。そのため、路地幅員は $6 \mathrm{~m}$ となるはずである。しかし 現在では、ソイ 13 の路地幅員は、建物間では平均 $2.0 \mathrm{~m}$ (最小 $1.68 \mathrm{~m}$ )、 あふ秃出しの生活財を含めると平均 $1.36 \mathrm{~m}$ （最小 $1.08 \mathrm{~m}$ ） となる。 すなわち、路地幅員の狭さは、セットバック部分への増築によって 生み出されている。

もう 1 つの特徴として、多様な材料、色彩、生活財のあふれ出し により、各建物が差別化されている点がある。ファサードの主要材 料として、RC とコンクリートブロック（以下、RCB）、木がある。 ソイ 13 の建物（27 軒）では、3 種類の材料をすべて使用している 建物（16 軒）が多く、2 種類（8 軒)、1 種類（3 軒）と続く。その 他の材料として、ビニールや煉瓦、スチール、トタンなどがある。

ファサードは多彩に塗装されている。ソイ 13 では、ファサード の色彩は白 (12 軒) ・茶 (9 軒) ・灰 (9 軒) ・青 (8 軒) ・ 緑 (3 軒) ・ 桃（3 軒）の計 6 色がある。そのうち白・青・緑・桃はペンキで塗 装された色である。塗装有りの建物（22 軒）が多く、塗装無しの建 物（5 軒）は少ない。

生活財のあふれ出しが多数確認できる。ソイ 13 の建物 1 軒当た りのあふれ出しの数は、平均 14.9 個、最大で 53 個、最小で 2 個之 なっている。具体的には、植木鉢（133 個）や心゙ンチ（15 個）、バイ ク (8 台)、物干し竿 $(23$ 本) などがある。

その他、路地に掛かる庇 (16 軒) が各建物に取り付けられている。 ソイ 13 における庇の出は平均 $0.79 \mathrm{~m}$ である。中には、路地を横断 する屋根（以下、路地屋根）がソイ 12 には 6 か所、ソイ 28 には 4 か所、ソイ 13 には 2 か所ある。構造には木やスチール、屋根材に 


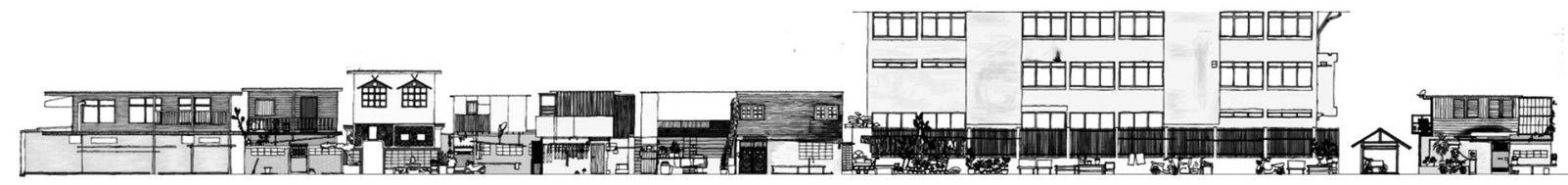

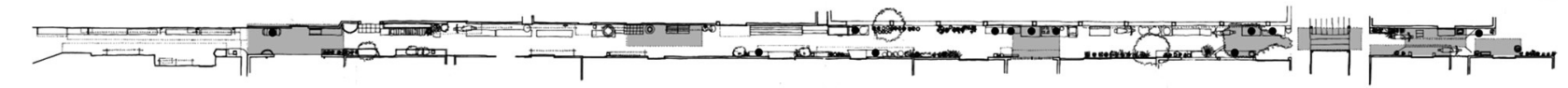

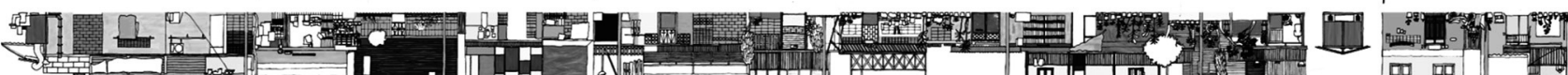

Soi12

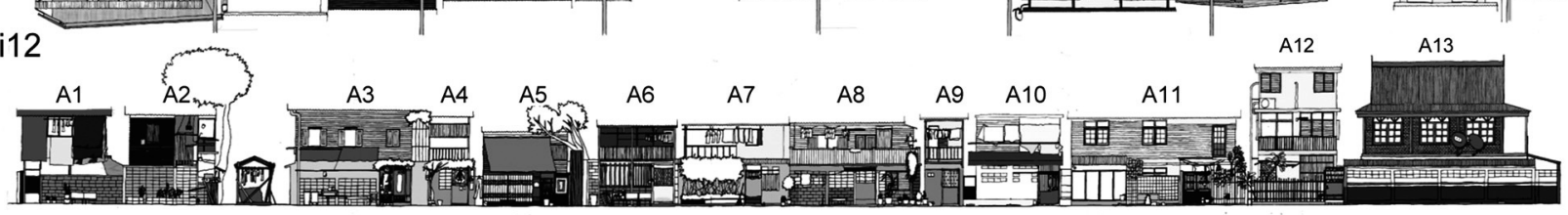

(1)

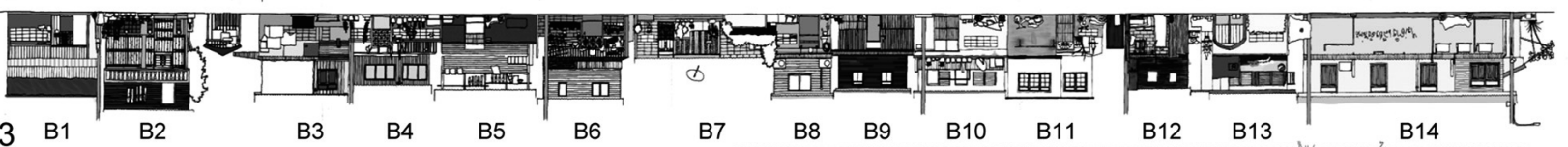

Soi13 B1

B3 $\quad$ B4 $\quad$ B5 $\quad$ B6

$\begin{array}{lllll}\text { B7 } & \text { B8 } & \text { B9 } & \text { B10 } & \text { B11 }\end{array}$

B12 B1

B14

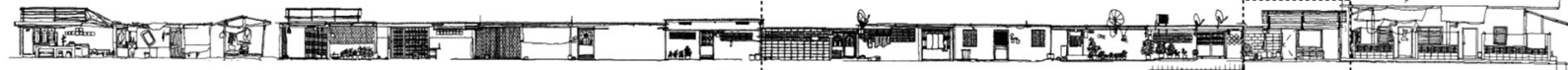 2.

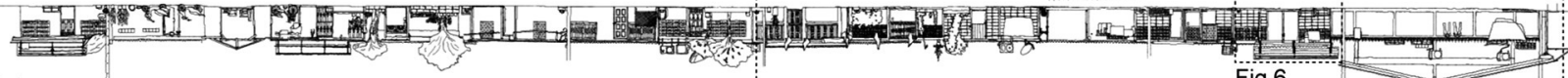 \\ Analyzing area of activity reserch(Table2)}

Soi28

Roofs over the alleys Benches A1-13 and B1-14 Building numbers(Table1)

Fig.5 Façade and plan of alley space

Table1 Date of alley space in Soi 13

\begin{tabular}{|c|c|c|c|c|c|c|c|c|c|c|c|c|c|c|c|c|c|c|}
\hline \multirow{3}{*}{\multicolumn{2}{|c|}{$\begin{array}{l}\text { Building } \\
\text { numbers }\end{array}$}} & \multirow{3}{*}{$\begin{array}{c}\text { Site } \\
\begin{array}{c}\text { Width } \\
(\mathrm{m})\end{array}\end{array}$} & \multicolumn{2}{|c|}{ Building } & \multicolumn{5}{|c|}{ Façade } & \multicolumn{3}{|c|}{ Alley } & \multicolumn{6}{|c|}{ Overflowing things } \\
\hline & & & \multirow{2}{*}{ Floors } & \multirow{2}{*}{$\begin{array}{c}\text { Eaves } \\
\text { level } \\
(\mathrm{m})\end{array}$} & \multicolumn{3}{|c|}{ Materials } & \multicolumn{2}{|c|}{ Colors } & \multirow{2}{*}{$\begin{array}{l}\text { Roofs } \\
(\mathrm{m})\end{array}$} & \multirow{2}{*}{$\begin{array}{l}\text { Width } \\
(\mathrm{m})\end{array}$} & \multirow{2}{*}{$\begin{array}{l}\text { Including } \\
\text { overflowing } \\
\text { things }(m)\end{array}$} & \multirow{2}{*}{ Benches } & \multirow{2}{*}{$\begin{array}{l}\text { Flower } \\
\text { pots }\end{array}$} & \multirow{2}{*}{$\begin{array}{l}\text { Clothing } \\
\text { poles }\end{array}$} & \multirow{2}{*}{ Bikes } & \multirow{2}{*}{ Others } & \multirow{2}{*}{ Total } \\
\hline & & & & & $\mathrm{RC}$ & RCB & W & $1 \mathrm{~F}$ & $2 \mathrm{~F}$ & & & & & & & & & \\
\hline \multirow{13}{*}{ A } & 1 & 6 & $2 \mathrm{~F}$ & 5.2 & - & 0 & 0 & $\mathrm{Gr}$ & $\mathrm{Br}$ & 0.3 & 2.12 & 1.64 & 2 & 12 & 1 & - & 3 & 18 \\
\hline & 2 & 6 & $2 \mathrm{~F}$ & 5.3 & 0 & 0 & 0 & $\mathrm{Gr}$ & $\mathrm{Br}$ & 0.6 & 2.03 & 1.34 & - & 5 & - & - & 3 & 8 \\
\hline & 3 & 9 & $2 \mathrm{~F}$ & 5.6 & 0 & 0 & 0 & Gn & $\mathrm{Gn}$ & - & 2.15 & 1.29 & 4 & 4 & 3 & - & 6 & 17 \\
\hline & 4 & 3 & $2 \mathrm{~F}$ & 5.3 & 0 & 0 & 0 & $\mathrm{Bl}$ & $\mathrm{Br}$ & 2.2 & 2.15 & 1.38 & - & 3 & - & - & 13 & 16 \\
\hline & 5 & 6 & $2 \mathrm{~F}$ & 4.4 & - & - & 0 & $\mathrm{Br}$ & Wh & 1.8 & 2.35 & 1.29 & 1 & 1 & - & - & 14 & 16 \\
\hline & 6 & 6 & $2 \mathrm{~F}$ & 4.8 & 0 & O & 0 & $\mathrm{Gr}$ & $\mathrm{Br}$ & - & 2.06 & 1.08 & 3 & 2 & 1 & - & 12 & 18 \\
\hline & 7 & 9 & $2 \mathrm{~F}$ & 4.8 & 0 & 0 & 0 & $P$ & Wh & - & 2.08 & 1.08 & - & 4 & 2 & - & 4 & 10 \\
\hline & 8 & 9 & $2 \mathrm{~F}$ & 4.9 & 0 & 0 & 0 & $\mathrm{Gr}$ & $\mathrm{BI}$ & 0.6 & 2.08 & 1.55 & 1 & 6 & 4 & - & 7 & 18 \\
\hline & 9 & 3 & $2 \mathrm{~F}$ & 5.1 & 0 & - & 0 & $\mathrm{BI}$ & Wh & - & 1.94 & 1.41 & - & 2 & 1 & - & 2 & 5 \\
\hline & 10 & 6 & $2 \mathrm{~F}$ & 5.1 & 0 & 0 & 0 & Wh & Wh & 0.5 & 1.94 & 1.53 & - & - & - & - & 2 & 2 \\
\hline & 11 & 12 & $2 \mathrm{~F}$ & 5.1 & 0 & - & 0 & Wh & Wh & 0.4 & 1.68 & 1.18 & - & 5 & 1 & - & 7 & 13 \\
\hline & 12 & 6 & $3 \mathrm{~F}$ & 8.2 & 0 & - & - & Wh & Wh & - & 1.68 & 1.68 & - & 2 & 1 & - & 7 & 10 \\
\hline & 13 & 10 & $2 \mathrm{~F}$ & 5.6 & 0 & - & 0 & $\mathrm{BI}$ & - & 0.3 & 1.68 & 1.24 & - & - & - & - & 4 & 4 \\
\hline \multirow{12}{*}{ B } & 1 & 6 & $2 \mathrm{~F}$ & 5 & 0 & 0 & 0 & $\mathrm{BI}$ & $\mathrm{BI}$ & 0.7 & 2.12 & 1.64 & - & 2 & - & 1 & 17 & 20 \\
\hline & 2 & 6 & $2 \mathrm{~F}$ & 5.7 & 0 & 0 & - & Wh & $\mathrm{Br}$ & - & 2.03 & 1.34 & - & 8 & 1 & - & 0 & 9 \\
\hline & 3 & 6 & $2 \mathrm{~F}$ & 4.8 & 0 & 0 & 0 & Wh & Wh & 0.4 & 2.15 & 1.29 & 1 & 6 & - & - & 21 & 28 \\
\hline & 6 & 6 & $2 \mathrm{~F}$ & 5.1 & 0 & 0 & 0 & $P$ & Wh & 0.6 & 2.06 & 1.08 & - & 17 & - & - & 36 & 53 \\
\hline & 7 & 12 & $1 \mathrm{~F}$ & 2.7 & 0 & 0 & & $\mathrm{Gr}$ & - & - & 2.08 & 1.08 & - & 8 & - & - & 5 & 13 \\
\hline & 8 & 6 & $2 \mathrm{~F}$ & 4.8 & 0 & 0 & 0 & $\mathrm{Gn}$ & $P$ & 0.6 & 2.46 & 1.55 & 1 & 4 & 1 & - & 13 & 19 \\
\hline & 9 & 6 & $2 \mathrm{~F}$ & 4.5 & - & - & 0 & $\mathrm{BI}$ & $\mathrm{Br}$ & 0.4 & 1.94 & 1.37 & - & 3 & 2 & - & 9 & 14 \\
\hline & 10 & 6 & $2 \mathrm{~F}$ & 4.5 & 0 & 0 & 0 & $\mathrm{Gr}$ & Wh & 0.5 & 1.94 & 1.53 & - & 20 & 1 & 1 & 8 & 30 \\
\hline & 11 & 6 & $2 \mathrm{~F}$ & 4.9 & 0 & - & 0 & $\mathrm{Gr}$ & Wh & - & 1.68 & 1.42 & - & - & 1 & 1 & 2 & 4 \\
\hline & 12 & 6 & $2 \mathrm{~F}$ & 4.5 & 0 & 0 & 0 & $\mathrm{Gr}$ & $\mathrm{Br}$ & - & 1.68 & 1.18 & 1 & - & 1 & - & 4 & 6 \\
\hline & 13 & 6 & $2 \mathrm{~F}$ & 4.8 & 0 & 0 & 0 & Wh & Wh & 0.5 & 1.68 & 1.68 & - & 7 & - & 1 & 4 & 12 \\
\hline & 14 & 10 & $2 \mathrm{~F}$ & 4.9 & 0 & 0 & 0 & $\mathrm{BI}$ & $\mathrm{BI}$ & - & 1.68 & 1.24 & - & - & - & 3 & 4 & 7 \\
\hline \multicolumn{2}{|c|}{ Average } & - & - & 4.99 & - & - & - & - & - & 0.79 & 2 & 1.36 & 0.6 & 4.9 & 0.9 & 0.3 & 8.2 & 14.9 \\
\hline \multirow{2}{*}{\multicolumn{2}{|c|}{$\begin{array}{l}\text { Max } \\
\text { Min }\end{array}$}} & - & - & 8.2 & - & - & - & - & - & 2.2 & 2.35 & 1.68 & 4 & 20 & 4 & 3 & 36 & 53 \\
\hline & & - & - & 2.7 & - & - & - & - & - & 0 & 1.68 & 1.08 & 0 & 0 & 0 & 0 & 0 & 2 \\
\hline
\end{tabular}

Colors / Wh: White Gr: Gray Br: Brown Bl: Blue Gn: Green P: Pink 


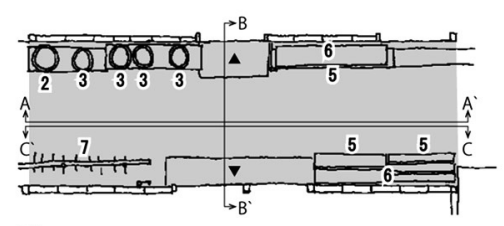

Plan

A-A' Section

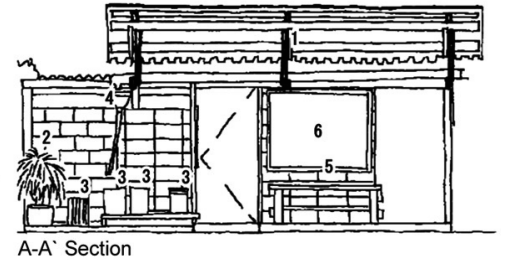

Ban karun

Table2 Activity date in Soi 28, Ban karun, Tuesday, 19th September 2017

\begin{tabular}{lcc}
\hline \multicolumn{1}{c}{ Activity date } & $\begin{array}{c}\text { Under the roof } \\
\text { over the alley }\end{array}$ & $\begin{array}{c}\text { Another } \\
\text { place }\end{array}$ \\
\hline Average time of staying(Minutes) & 13.9 & 1.0 \\
Resting (Peoples) & 17 & - \\
Talking (Peoples) & 30 & 2 \\
Eating (Peoples) & 11 & 1 \\
Washing (Peoples) & - & 3 \\
Playing (Peoples) & 3 & 1 \\
Another activities (Peoples) & 9 & 5 \\
Total people over doing 2 activities (Peoples) & 25 & 0 \\
Total people of doing activities (Peoples) & 48 & 11 \\
\hline Total people (Peoples) & \multicolumn{3}{c}{137} \\
Bikes or Bicycles (Holders) & \multicolumn{3}{c}{84} \\
\hline
\end{tabular}

はビニールやトタンなどを使用する仮設的なものが多い。

これまでの中で、生活財のあふれ出しと路地屋根は、公有地であ る路地を私的に活用するものであり、ルールから逸脱する建築的実 践である。路地の特徴について把握したところで、以下では、路地 空間の使い方について、アクティビティ調査の資料をもとに述べる。

\section{4-2.路地空間の使い方}

住民の路地空間の使い方について、生活財のあふれ出しや路地屋 根がどのような影響を及ぼすかについて分析する。アクティビティ 調查は、ソイ 12 、ソイ 13 、ソイ 28 ごとに、休日と平日の $10: 30$ 〜 $17: 30$ に実施した。以下では、路地屋根があるソイ 28 の $9 \mathrm{~m}$ 路 地側での調査をもとに述べる（Fig.6・Table2）。この場所を選定し た理由は、路地屋根の下にはベンチなど、滞在するための仕掛けが 確認できる一方で、それ以外ではそれらが確認できないなど、条件 が対照的である。そのため、空間的な仕掛けとアクティビティの関 係性が理解しや寸いと考えたからである。

ソイ 28 の $9 \mathrm{~m}$ 路地側には路地屋根がある。路地屋根は、木の梁 や束、母屋、垂木、栈木など構造体の上にスレートが莫かれている。 その下には、荷役労働者が居住する賃貸住宅が面している。その反 対側の住宅では、入り口が約 $2 \mathrm{~m}$ と大きく開放されており、路地か ら見える位置にテレビが置いてある。住宅間の往来は裸足が多い。 路地屋根の下には、3 つのベンチと荷役労働者の勤務表が記載され ているホワイトボードなどがある。

その路地屋根の下では、住民のアクティビティが多数確認できる。 そこには、荷役労働者と反対側の住宅の居住者が集まり、休息（テ レビを見るバンチに座る）、会話、食事、洗濯（物干し竿に衣服を干 す・取り込む)、娛楽（煙草を吸う/子供が走り回る・ゲーム）、その 他（電話をかける/着替え/荷役労働の勤務表の確認 ・記入/排水溝に ゴミを捨てる）などがあった。

これらの行為を場所ごとに分類したところ、路地屋根の下では、 住民のアクティビティが顕著であることがわかった。通行人数 137 人のうち、路地屋根の下で何かしらの行為をした人が、48 人いるの に対して、それ以外では 11 人しかいない。また、前者は 1 人当た り平均 13.9 分（最大 133 分）滞在しているが、後者は平均 1.0 分
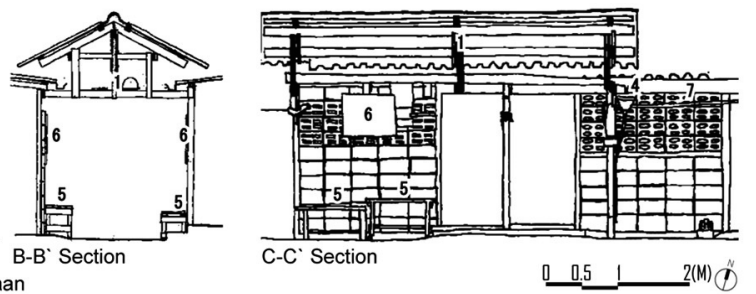

（最大 6 分）しか滞在していない。さらに、前者では複数の行為を した人が 28 人いるにもかかわらず、後者では 1 人もいない。

これらの結果から、路地屋根やベンチなどの空間的な仕掛けが、 路地でのアクティビティを誘発したと考えられる。路地屋根は直射 日光を遮り温度上昇を防ぐ。ベンチは寝転がったり、座ったりする 場所になる。このような住民の工夫により、通常であれば住宅内部 での行為（休息/食事など）が路地でも可能になったと考えられる。 ここで、このような空間的な仕掛けを生み出す住民の価值観とし て、「ノーク・バーン」という言葉に着目する。「ノーク」は「外」、 「バーン」は「家」を意味し、その範囲は、建物の間口と同じ幅の 外部空間である。路地は港湾局が所有する公的な土地だが、この「ノ ーク・バーン」では、生活財のあふれ出しや路地屋根の設置などさ まざまな実践が確認できる。すなわち、この「ノーク・バーン」を 私用するという価值観が住民間で共有されており、それが公的な路 地空間を私有地のように活用することを促すと考えられる。

ここでは、生活財のあふれ出しや路地屋根が、路地空間での住民 のアクティビティを促進させていることを見出した。以下では、路 地に面する建物を形式ごとに分類して、ルールから逸脱する建築的 実践について分析する。

\section{4-3. 現状の建物形式とルールから逸脱する建築的実践}

現在では、70 ライ地区における大半の建物が、建設ルールから逸 脱した増築もしくは建替をおこなっている。すなわち、70 ライ地区 の路地空間は、ルールから逸脱する建物群により成り立っていると 考えられる。以下では、それらの建物形式の定義をおこなう(Fig.7)。

ソイ 12 ・ソイ 13 では、「建設ルール型」の他に 2 種類の建物形式 がある。1つ目は「前増築型」であり、「建設ルール型」から敷地前 面に増築した建物を指す。 2 目は「総 2 階型」注 21 ) であり、路地 際から 2 階建てが建設されている建物を指す。これらの建物は、敷 地前面の夕間口一杯に建設されていることが特徴である。

ソイ 28 では、「建設ルール型」および「前増築型」の他に、3 種 類の建物形式がある。1つ目は「前・後増築型」であり、「前増築型」 に加え、敷地後方に増築した建物を指寸。 2 つ目は「前・2 階増築 型」であり、「前増築型」に 2 階を増築した建物を指す。 3 つ目は 「前・後・2 階増築型」であり、「前・後増築型」に 2 階を増築した 建物を指寸注 22 )。この中で「前・後・2 階増築型」と「前・後増築型」 は、ソイ 28 の南側でしか見られない。これらの建物は、供給部分に 対して、前後に増築することが一般的である。

上記の分類をもとに、建物形式について分析する。ソイ $12 \cdot$ ソイ 13 (49 軒) では、「総 2 階型」(25 軒) が最も多く、「前増築型」(16 軒)、「建設ルール型」（8 軒）注 23 ) と続く。一方、ソイ 28 (30 軒) では、「前増築型」（12 軒）と「前・後増築型」（12 軒）が大半を占 め、「建設ルール型」(3 軒)、「前・ 2 階増築型」 ( 2 軒)、「前・後 ・ 2 階増築型」（1軒）と続く。ソイ 12 ・ソイ 13 とソイ 28 では、建 


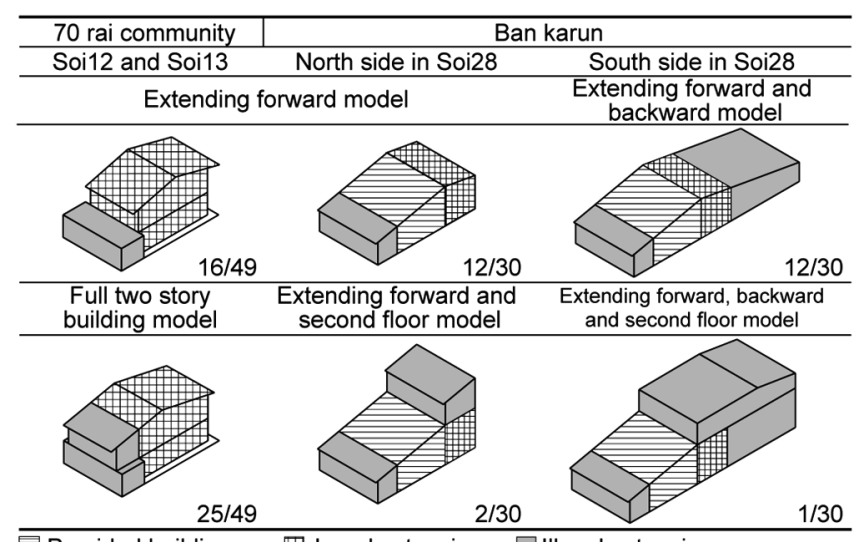

胆Provided buildings 四 Legal extension $\square$ Illegal extension

Fig.7 Currently building formats except "Legal extension on provided building model"

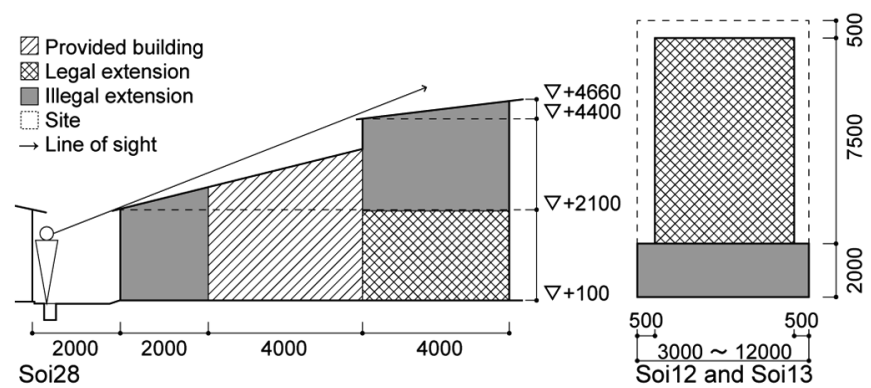

Fig.8 Illegal construction practices

設ルールから逸脱した建物が大半である。

これらの建物形式から、ルールから逸脱する建築的実践を 2 つ見 いだせる（Fig.8）。1つは 2 階の増築である。バン・ガルンの「前・ 2 階増築型」および「前・後・2 階増築型」では、2 階部分を路地際 から $6 \mathrm{~m}$ 後方に増築している。路地幅 $2 \mathrm{~m}$ 、軒高 $2 \mathrm{~m}$ 、庇 $0.2 \mathrm{~m}$ のと き、この手法で 2 階を増築すると、路地に掛かる庇が視線を遮り、 2 階が地上から見えなくなる。このように、バン・ガルンでは 2 階 の増築は禁止されているにもかかわらず、実際には建設されている。

もう 1 つは 1 階部分の増築である。敷地前面への増築は分類した 建物形式すべて、また敷地後方への増築は「前・後増築型」と「前・ 後・2 階増築型」で確認できる。住民は、増築に関して港湾局への 申請が不用である点を利用して多様な増築をおこなう。一方これら の増築は、所有する敷地の範囲内に限られていることも特徵である。

これまで、ルールから逸脱する建築的実践について分析した。70 ライ地区では、(1)生活財のあふれ出し、(2)路地屋根の設置、(3)敷地 前面への増築、(4)敷地後方への増築、(5) 2 階の増築がある。以下で は、住民へのヒアリングをもとにこれらの実践について考察する。

\section{4-4. 住民の価値観}

最初に建物の高層化（5)）について見てみよう。住民にバン・ガ ルンの 2 階建てについて質問すると、「2 階建ては建設ルールで禁止 されている (2017.9, バン・ガルン在住, 35 歳, 女性)」としながら も、「実際に建設してもそれを注意する住民はいない（同上）」とい う。この回答は、ルール上禁止されている実践であっても、住民は 建物の高層化を必ずしも問題視するわけではないことを示している。

次に、建築面積の拡大（3)・(4)）および路地空間の私有（1)・(2) について見てみよう。住民に、敷地内の空いている部分の私有につ いて質問すると、「自身が所有する敷地の幅まで自由に使っていい
Table3 Number of illegal construction practices

\begin{tabular}{lccccc}
\hline Illegal construction practices & Soi12 and Soi13 & Soi28 & Total & Number & $\%$ \\
\hline (1) Overflowing things & 49 & 26 & 75 & 79 & 94.9 \\
(3) Extending forward & 41 & 27 & 68 & 79 & 86.1 \\
(4) Extending backward & - & 13 & 13 & 15 & 86.7 \\
(2) The roofs over the alleys & 8 & 4 & 12 & 79 & 15.2 \\
(5) Extending second floor & - & 3 & 3 & 30 & 10.0 \\
\hline
\end{tabular}

(2018.9, 70 ライ地区在住, 60 歳, 男性)」という。また、そこへの 増築について質問すると、「建設ルール（建築面積制限）は理解して いる（2018.5, 70 ライ地区在住，47 歳，女性）」とした上で、「増築 はみんなやっているし、路地に入らなければ大丈夫だ（同上）」とい う。これらの回答は、住民が建設ルールを理解しながらも、意図的 に前面や後方に増築していることを示している。しかしながら、そ れらの実践には一定の条件があり、その根拠を「みんな」、すおお 大半の建物で確認できる実践か否かで判断している。

ここで、ルールから逸脱する建築的実践を「みんな」がやってい るか否かについて分析する (Table3)。結果として、(1)と (3)、(4)は「み んな」がやっており、(2)と(5) (5)部でしか確認できない。一方、70 ライ地区の全 $2 \mathrm{~m}$ 路地を対象とすると、(2)（90 軒）、(5)（14 軒）が 一定数あることは付け加えておく。しかし、ソイ $12 \cdot 13$ 、ソイ 28 に限っていえば、後者は、「みんな」がおこなっているわけではなく、 その正当性を主張する根拠に乏しいと考えられる。

例えば、敷地前面への増築とバン・ガルンでの 2 階の増築は、「み んな」がやっているか否かが異なる。前者は路地から見える位置に、

「みんな」がおこなっているが、後者は路地から見えない位置に、 ごく少数に限られている。これは、2 階の増築がそもそも認知され ていないため、「みんな」が真似することができない可能性がある。 さらにいえば、視覚的に隠すという工夫は、「みんな」がやっている という大義名分が使えない結果として、生み出された可能性もある。

ここで、路地空間に関する実践 (1)と (2)) と建物に関する実践 (3) から（5)）に分けて、住民が許容できない実践について検討する。住 民の言説を振り返ると、ルールから逸脱する実践をおこなう際に、

「路地に入らなければ」や「所有する敷地の幅まで」などの条件を 加える。これらの条件は、「みんな」がやっているか否かにかかわら ず、ルールから逸脱する建築的実践における最低限守るべき取り決 め、すなわち住民の許容範囲を示している。

前者では、路地空間の通行を最低限確保する点が共通している。 路地空間の物理的特徴で分析したように、路地幅員は最小で $1.68 \mathrm{~m}$ 、 あふれ出しを含めた場合でも $1.08 \mathrm{~m}$ の動線を確保している。しかし、 再開発の段階では路地幅は $2 \mathrm{~m}$ とされており、実際には、住民の実 践は「路地に入」っていないわけではない。つまり住民の発言をい いかえれば、路地空間の通行を最低限確保することを示しており、 逆に通行を阻害するような実践は許容されていない。

一方後者では、自身が所有する敷地の範囲内に限られていること が共通している。前述したように、1 階の増築は所有する敷地の範 囲内に限られており、2 階の増築もその範囲を超えることはほとん どない。裏を返せば、建物の増築をする際に、他者の土地を侵略す ることは、住民間でも許容されていない。

以上から、70 ライ地区におけるルールから逸脱する建築的実践は、 あくまで住民間で許容できる範囲一路地に入らない・自分の敷地内 に限るーに限られている。

では住民は、このルールから逸脱する建築的実践をどのように共 


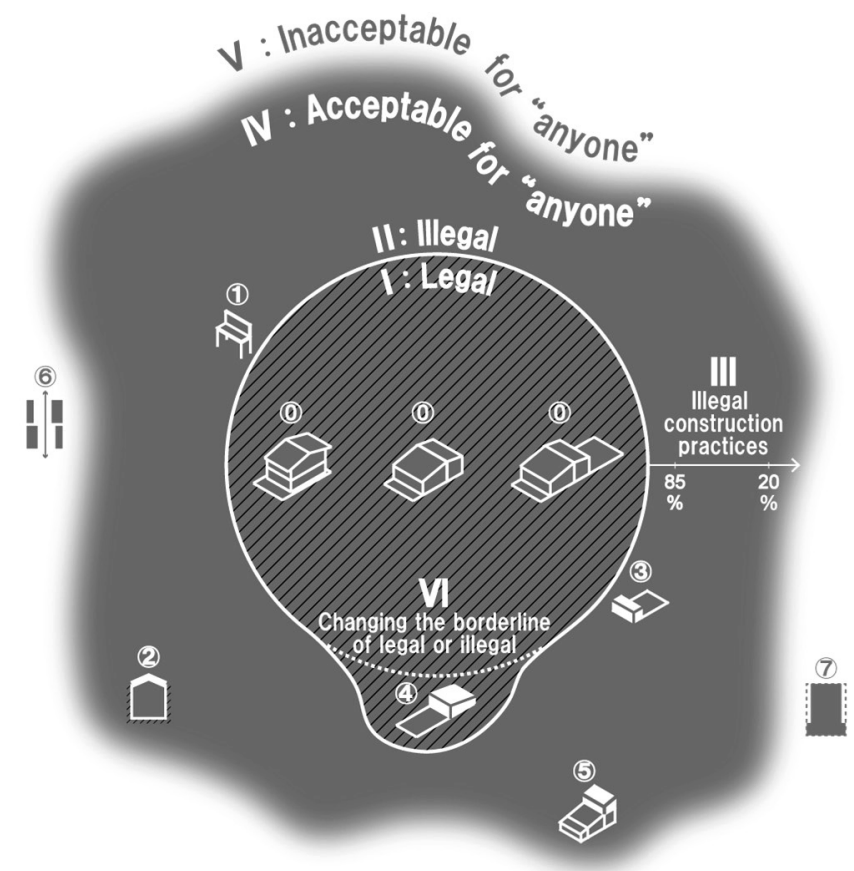

\begin{tabular}{ll}
\hline I :Legal & (0) Legal extension on provited building model \\
\hline II:Illegal and & (4) Extending backward \\
IV:acceptable for "anyone" over $85 \%$ & (1) Overflowing things \\
\hline II:Illegal and & (3) Extending forward \\
IV:acceptable for "anyone" under $20 \%$ & (4) Extending backward \\
\hline II:Illegal and & (2) The roof over the alley \\
V:inacceptable for "anyone" & (5) Extending second floor \\
\hline
\end{tabular}

Fig.9 Diagram of Illegal construction practices

有しているのか。ここでは、1992 年に東北部から 70 ライ地区に移 住してきた住民を参考にする。この住民は、建物を新築する際に、

「周りの住宅を参考にして建設した（2017.9，70 ライ地区在住， 72 歳, 女性)」という。そして建設された建物は、70 ライ地区における 一般的な建物形式 -2 階建て、 1 階 $\mathrm{RC}$ 造・2 階木造の「前増築型」 一となった。つまり、この住民はすでに存在する周りの建物から、 住民の許容できる/できないという線引きを解釈した。

しかしながら、住民の許容できる/できないという線引きは厳密で はなく、時間とともに変化していくと考えられる。つまり住民は、 周りの建物を見ることで、住民間で共有されたルールを解䣋する。 そして、自身の建物にもその実践を適用する。それだけではなく、 新たに建設された建物は、周りの住民に対しても解釈される対象と なる。すなわち、建物の変化とともに、実践の根拠も変化していく と考えられる。現在、一部でしか確認できない実践は、いずれ「み んな」がやっている実践へと変化していく可能性がある。

まとめると、これらの実践は、建物を通して暗默のうちに共有さ れていることに加え、常に変化していく点に特徴がある注 24)。

それだけではなく、住民の実践が計画者の枠組みに影響を与える こともある。例えば、バン・ガルンでは、敷地後方の空き地への増 築は禁止されていたが、2000 年頃から借地化が開始された。しかし、 1986 年の段階で寸でに「建設ルール型」から「前後増築型」へ増築 した住民もいた。この事実から、ルールを更新した後に増築したの ではなく、住民が勝手に増築したので、借地化せざるを得なかった 可能性がある注 25)。すなわち、住民のルールから逸脱する建築的実
践により、既存の枠組みが住民の都合のいいように再構築されたと 考えられる。

70 ライ地区におけるルールから冕脱する建築的実践についてま とめると以下のようになる（Fig.9）。70 ライ地区では、建設ルール による合法/違法の線引きがおこなわれた（Fig.9；Ｉ，II， (0)）。にも かかわらず、住民はそれらから逸脱する建築的実践をおこなう（III）。 なぜなら、住民は合法/違法とは異なる、住民間で許容できる/できな いという新たな線引きを生み出したからだ (IV, V)。これによって、 住民の生活領域は、合法/違法の枠外一と拡大した。また住民はこれ らの実践の正当性を「みんな」がやっているか否かで判断する (1) 一(7)。そして、「みんな」がやっているか否かは時間とともに変化 していく。それだけではなく、このような実践の変化とともに、住 民が許容できるか否かの線引きも変化すると考えられる。この線引 きは合法/違法とは異なり、明確な判断基準があるわけではない。そ れをいかに解釈するかは、住民 1 人ひとりに委衫られている。さら に、これら実践は、合法/違法の線引きを変化させる可能性を秘めて いる（VI）。

\section{5. おわりに}

本稿では、70 ライ地区を事例に、路地空間におけるルールから逸 脱した建築的実践に着目した。その結果、以下の 3 点の知見を得た。

1） 70 ライ地区では、ルールから逸脱する建築的実践として、(1)生 活財のあふれ出し、(2)路地屋根の設置、(3)敷地前面への増築、 (4)敷地後方への増築、(5) 2 階の増築がある。

2）これらの実践は、住民間で許容できる範囲一路地に入らない・ 自分の敷地内のみ一に限られている。すなわち、これらの実践 がなくならないのは、合法/違法という線引きに対して、住民が 許容できる/できないという枠組みを再設定するためである。

3）住民は、これらの実践の正当性を「みんな」がやっているか否 かで判断する。

本稿では、住民がルールから逸脱する建築的実践により、計画者 の枠組みとは異なる新たな秩序を形成する実態を明らかにした。し かし、本稿では計画者が制定した合法/違法の観点から判断できる要 素しか述べられていない。さらに、住民が許容できるか否かの基準 は、合法/違法の線引きがない場合においても適応可能であると考え られる。この点に関しては、次稿での課題としたい。

注

注 1) スラムとは物理的な居住環境の劣悪さにより判断される概念である。 一方、不法占拠地区とは、土地の所有者と契約関係にない居住者が住みつ く地区を指寸概念である。本稿では秦の定義を参照し、スラムと不法占拠 地区、スラム改善事業地も含めてスラムと定義する ${ }^{11}$ 。

注 2) クリアランス型開発とは、市街地にあるスラムをクリアランスし、郊 外に建設した公営住宅に住民を移転させる事業を指す。

注 3) S\&S とは、歩道や下水道など最低限のインフラ整備をおこない、住宅 は住民が自力建設する事業を指す。

注 4）タイのスラム地区数は 1960 年の 361 か所から 1980 年には 1000 か所 を超え、2006 年段階では 1774 か所まで急増した 2)。

注 5）スラム改善事業は、1960 年代から 1970 年代ではクリアランス型開 発、1970 年代から 1980 年代では $S \& S$ などの住民参加型事業、1990 年 代以降ではコミュニティ形成を主体とする政策へとシフトしていった。 注 6）スラム改善事業には、計画者の合理性が反映されている。例えば、田 中が調査したスラム改善事業地では、居住者による増改築が前提とされて いた ${ }^{3)}$ 。つまりこの事業では、計画者が想定する合理的な増改築のパター 
ンが存在し、それに適したコアハウスの規模および配置が決定されたと考 えられる。しかしながら、田中は、計画者の想定とは異なる増改築が実施 されていたことに加え、S\&S の事後評価は、居住開始後 1 年後におこな われ、計画意図の説明不足により、適切な評価ではなかったと指摘する 3)。

注 7）これらの研究 ${ }^{4) 5}$ (は、タイ住宅公社の設立など、後のタイのスラム改 善事業に影響を与えた。しかしながら、1990 年以降貯蓄組合などのコミ ユニティ形成に主眼がおかれ、そのような研究は減少している。

注 8) 注 1 を参照せよ。

注 9）防火や井戸の水質に関するもの、路地への 2 階の張り出し制限などが あり、これらは住民同士の話し合いをもとに制定されたという99

注 10）具体的には、1957 年のクロントイ市場およびショップハウス建設の ための開発、1962 年の道路建設、1964 年の防波堤建設、1968 年の税関 建設、1970 年の防波堤拡大、1981 年の倉庫建設などがある ${ }^{12)}$ 。

注 11）住民の立ち退きへの抵抗は、住民委員会の設立や王への嘆願書の提出 などがあり、その結果、近郊への移住（1968 年）や再定住計画（1970 年、1977 年、1985 年) などを獲得した ${ }^{12)}$ 。

注 12）土地分有事業とは、既存のスラムをクリアランスし、土地を居住地と 商業地の 2 つ分け開発する事業である。この事業は、クロントイ再開発 計画でも用いられ、居住地域用と港湾開発用の 2 つ土地を分け開発をお こなった。計画案によれば、全体の計画面積は 407.8rai（1rai $=40 \mathrm{~m} \times$ $\left.40 \mathrm{~m}=1600 \mathrm{~m}^{2}\right)$ うち、居住地域の面積は $248.8 \mathrm{rai}$ である。

注 13）居住地域ごとに異なる開発が実施された。ゾーン $1 \cdot 2$ 地区では再区 画事業と S\&S、ゾーン 3 地区では再区画事業、フラット地区では集合住 宅の建設がおこなわれた。

注 14）注 12 を参照せよ。

注 15）住民によれば、70 ライ地区の面積は約 66rai から 67rai であるとい う。敷地面積の具体的な供給は不明であり、地区全体の面積も計画段階か ら変化したと考えられる。

注 16）現在では、クロントイスラムを対象とした再開発が計画されており、 商業施設や鉄道などを建設する予定である。

注 17）実際には、自力建設は $36 \%$ の、大工への委託が $25 \%$ 、自力建設お よび大工への委託の複合が $49 \%$ たたという 12 )

注 18）住宅の増改築を調査した 9 軒中、建設当初から建設ルールを逸脱し た住宅は 1 軒もない。このことから、1985 年の段階で、建設ルールを順 守していた建物も存在していたと考えられる。

注 19）バン・ガルンの範囲について具体的に示された資料はない。そのため 本稿では、供給された建物の分布からバン・ガルンの範囲を設定した。

注 20）その他として、(1)敷地面積 $102 \mathrm{~m}^{2}$ を除くす心゙て、2 階建て以上、 RC 造（69 軒、うち 9 軒バン・ガルン）(2)木造、その他1)と同じ（22 軒） (3)敷地面積 $30 \mathrm{~m}^{2} \cdot 90 \mathrm{~m}^{2} \cdot 120 \mathrm{~m}^{2} \cdot 120 \mathrm{~m}^{2}$ 以上、1 階建て、木造（15 軒、 ちち 6 軒バン・ガルン) (4) RC 造、その他(1)と同じ (8 軒)、その他 分類に当てはまらない建物（4 軒、すべてバン・ガルン）がある。

注 21）「総 2 階型」は建替の可能性もあるなど、増築か否かの判断が困難 なため、増築という言葉を使用していない。

注 $22 ）$ ソイ 12 ・ソイ 13 では 2 階建ての建設が認められている。そのた め、「前・ 2 階増築型」と「前・後・ 2 階増築型」は、1 階建てまでしか認 められていないバン・ガルンの 2 階建てのみを指す形式として扱う。

注 23）「建設ルール型」の 8 軒のうち、2 軒は 3 階建ての $\mathrm{RC}$ 造である。こ の理由は、3 階建てや RC 造の建物を建設寸るために、技術者を雇わなけ ればならず、建設ルールを遵守せざるを得なかった可能性が考えられる。

注 24）このような、家屋が人や慣習などさまざまな要素との相互関係の上に 成り立つという特徵は、先行研究でも指摘されている ${ }^{13)}$ 。この研究によれ ば、慣習を重んじるアカ族の人々は、その慣習にもとづき、特定の形式を 持つ家屋を建設することに執着する。そのように建設された家屋は、慣習 にしたがっていることを示す物質的根拠となるだけではなく、その慣習を 共有する媒体としての役割を果たす。それだけではなく、このような手法 で共有された慣習は多様に解釈され、その解釈をもとに建設される家屋も 多様化していくという。

注 25）このような事例は、不法占拠地区の移転補償事業について論じた金菱 の研究でも指摘されている ${ }^{14)}$ 。金菱によれば、道徳的観点から、人々の違 法ないしは不法である実践の正当性が認められ、合法/違法の基準が変化し たという。
1) Hata, T.: The Study of Participatory Town Planning on Urban Slum, Thailand, Akashi Publisher, 2005(in Japanese)

秦辰也：タイ都市スラムの参加型まちづくり研究, 明石書店, 2005

2) Endo, T.: Living with Risk - Precarity \& Bangkok's Urban Poor, NUS Press, 2010(in Japanese)

遠藤環：都市を生きる人々 -バンコク・都市下層民のリスク対応, 京都大学 学術出版会, 2010

3) Tanaka, M. et al.: Transitional Process of the Corehouses at Tung Song Hong Planned Settlement in Bangkok, Journal of Architecture, Planning and Environmental Engineering(Transactions of AIJ), No.512, pp.93-99, 1998.10(in Japanese)

田中麻里ほか 3 名：トゥホンソン計画住宅地（バンコク）におけるコアハ ウスの増改築プロセスに関する考察, 日本建築学会計画系論文集, 512 号, pp.93-99, 1998.10

4) Thammasat University.: Klongtoey - A Social Work Survey of Squatter Slum, Bangkok, Thammasat University, 1971

5) Hongladaromp, T.: KLONGTOEY 1973 - A House to House Survey of the Squatter Slum the National Housing Authority of Thailand, Asian Institute of Technology, 1973

6) Chiba, K., Yano, M. and Iwata, E.: Squatter - Urban housing, Vol.6, Kajima Institute Publisher, 1973.6(in Japanese)

千葉桂司, 矢野正和, 岩田悦次：不法占拠 - 都市住宅 7306 , 鹿島研究所出 版会, 1973.6

7) Funo, S.: World of Kampung - The Dwellings History in Jawa, Indonesian, PARCO Publisher, 1991(in Japanese) 布野修司：カンポンの世界 - ジャワの庶民住居誌, PARCO 出版, 1991

8) Tamura, J. and Shima, N.: A Research on Informal Housing Supply Mechanism in Site and Services Areas - The Case of 70 Rai District, Bangkok, The City Planning Institute of Japan, No.10, pp.213-216, 2012.2(in Japanese)

田村順子, 志摩憲寿: サイト・アンド・サービス地区におけるインフォーマ ルな住宅供給メカニズムの実態 - バンコク・70 ライ地区を事例として，日 本都市計画学会都市計画報告集, No.10, pp.213-216, 2012.2

9) Okabe, A. et al.: History and Actual Situation of Slumism and Creating Ideas on Concentration - The Case Study of Cikini, Jakarta, Indonesian, Chapter5, In Muramatsu, S. et al.(Eds.): Megacities Vol.6 - Further Concentration in Megacities, Tokyo University Publisher, pp.175-223, 2017(in Japanese)

岡部明子ほか 4 名：スラム化の経緯と実態, 超高密度が生む知恵 - チキニ を事例に, 村松伸ほか 3 名: メガシティ 6 - 高密度するメガシティ, 東京大 学出版会, pp.175-223, 2017

10) Ono, H. and Kidokoro, T.: Development Patterns in Informal Settlements - Understanding the Spational Formation and Management of Informal Settlements in Nairobi (1), Journal of Architecture and Planning(Transactions of AIJ), Vol.83, No.743, pp.8391, 2018.1(in Japanese)

小野悠, 城所哲夫：インフォーマル市街地における開発形態の特質 - ナイ ロビのインフォーマル市街地における空間マネジメントに関する研究 (1), 日本建築学会計画系論文集, 83 巻, 743 号, pp.83-91, 2018.1

11) Matsuda, M.: Resisting City - World of Immigrant in Nairobi, Iwanami Publisher, 1999(in Japanese)

松田素二：抵抗する都市－ナイロビ移民の世界から，岩波書店, 1999

12) Boonyabancha, S. et al.: SIX CHAPTER OF KLONGTOEY - A Case Study of Struggle and Housing Development by Land-sharing, Bangkok, Thailand, Unpublished report, 1987

13) Shimizu, I.: Ethnography of Houses and Residents - Interaction between the House and the Akha of Northern Thailand, Fukyo Publisher, 2005(in Japanese)

清水郁郎：家屋とひとの民族誌 - 北タイ山地民アカと住まいの相互構築誌, 風響社, 2005

14) Kanebishi, K.: Sociology of Living Law, Shinyo Publisher, 2008(in Japanese)

金菱清: 生きられた法の社会学, 新曜社, 2008 


\title{
ILLEGAL CONSTRUCTION PRACTICES ON ALLEY SPACE
}

The case study of 70 rai community, Klongtoey, the slum improvement project area, Bangkok, Thailand

\section{Takuya $\mathrm{ABE}^{* 1}$ and Ikuro SHIMIZU*2}

\author{
${ }^{* 1}$ Freelance, M.Eng. \\ ${ }^{* 2}$ Prof., School of Architecture, Shibaura Institute of Technology, Ph.D.
}

Historically, the slums increased in the developed countries with recent modernization and today it becomes the serious problem to be improved. Toward the problem, governments implemented various improvement projects which prepared the legal restrictions on housing and construction to improve the living environment of the slums. But the slums are still existing with illegal construction practices by residents. This paper aims to clarify the reason why people take the illegal way of construction to make their living by analyzing alley space in 70 rai community, Klongtoey, Bangkok, Thailand. The primary data were collected by intensive field work including the drawing of the map of the community, façade and plan of alleys and houses, activity in the alleys, detailed information on residents' everyday life by interview.

First, the government's legal restrictions on housing and construction in 70 rai community which was implemented in Site and Service Project at 1985 is described. Building in 70 rai community observed the legal restriction on construction at 1985. In this paper, the houses which were built observing the legal restriction on construction is defined as "Legal extension on provided building model".

Second, currently living space in 70 rai community will be analyzed to understand general model. This paper analyzes area of site, the number of the floors of each house, and structure. As a result, in 70 rai community, area of site is classified into 4 types and second story with the structure of reinforced concrete and wood are popular. In the area called Ban karun, where the poorest citizens lived, area of site is 2 type and one story with structure of reinforced concrete are popular.

Third, this paper analyzes the ways how to use alley by focusing Soi 12, Soi 13, and Soi 28. Various things are overflowing to outside and people tend to stay under the roof over the alley. It is common that people are talking, resting, eating under the roof and so on. Overflowing things and roofs over the alley work as spatial device and cause people's specific activity in the alley.

Finally, this paper clarifies illegal construction practices. There are few "Legal extension on provided building model" in Soi 12 and Soi 13 and also in Soi 28. The illegal construction practices can be seen in almost all houses. Moreover, there are 2 types both in Soi 12 and Soi 13. In addition, there are 3 types only in Soi 28. In this paper, illegal construction practices are clarified as overflowing things, the roof over the alley and extending forward, backward and second floor. Following the factors, illegal construction practices are considered based on interview for residents. As a result, illegal construction practices is limited only within the acceptable or allowable level among people. On the contrary residents see whether or not are prevailing among people, "anyone" had already done those illegal practices. It cases the illegal practices. 